\title{
UPAYA PENINGKATAN KEMAMPUAN MEMORI DAN PRESTASI BELAJAR SISWA PADA MATERI KOLOID DENGAN MODEL PEMBELAJARAN COOPERATIVE INTEGRATED READING AND COMPOSITION (CIRC) DILENGKAPI MEDIA WEBQUEST PADA SISWA KELAS XI IPA 2 SEMESTER II SMA N 2 BOYOLALI TAHUN PELAJARAN 2016/2017
}

\author{
Rizki Irsyadi ${ }^{\star}$, Mohammad Masykuri, dan Sri Yamtinah \\ Program Studi Pendidikan Kimia, FKIP,Universitas Sebelas Maret, Surakarta, Indonesia \\ *Keperluan korespondensi, telp: 085725603312, email: rizkiirsyadi2708@gmail.com
}

\begin{abstract}
ABSTRAK
Tujuan penelitian ini adalah untuk meningkatkan kemampuan memori dan prestasi belajar siswa pada materi sistem koloid melalui penerapan model pembelajaran CIRC (Cooperative, Integrated, Reading, and Composition) dilengkapi media WebQuest. Penelitian ini menggunakan metode penelitian tindakan kelas yang terdiri dari 2 siklus. Subyek penelitian ini adalah siswa kelas XI IPA 2 SMA N 2 Boyolali tahun pelajaran 2016/2017. Sumber data penelitian diperoleh dari siswa, guru dan peristiwa (kegiatan siswa). Teknik pengumpulan data melalui observasi, wawancara, kajian dokumen, angket dan tes. Teknik analisis data penelitian ini adalah deskriptif kualitatif. Hasil penelitian menunjukkan bahwa penggunaan model pembelajaran CIRC dilengkapi WebQuest dapat meningkatkan kemampuan memori dan prestasi belajar siswa pada materi koloid. Peningkatan kemampuan memori dapat dilihat dari kenaikan presentase siswa pada siklus I 54,54\% menjadi 78,79\% pada siklus II. Prestasi belajar siswa dapat dilihat pada aspek kognitif, afektif dan psikomotor. Pretasi belajar aspek kognitif pada siklus I sebesar 57,58\% menjadi $81,82 \%$ pada siklus II. Prestasi belajar aspek afektif mencapai 93,94\% pada siklus I dan meningkat menjadi $96,97 \%$ pada siklus II. Prestasi belajar aspek psikomotor pada siklus I sudah mencapai $100 \%$.
\end{abstract}

Kata kunci: CIRC, WebQuest, kemampuan memori, prestasi belajar, koloid.

\section{PENDAHULUAN}

Kimia merupakan ilmu yang termasuk dalam IPA. Kimia merupakan ilmu yang pada awalnya diperoleh dan dikembangkan berdasarkan percobaan (induktif) namun pada perkembangan selanjutnya kimia juga diperoleh dan dikembangkan berdasarkan teori (deduktif). Kimia adalah ilmu yang mencari jawaban atas pernyataan apa, mengapa dan bagaimana gejala-gejala alam yang berkaitan dengan komposisi, sturktur, dan sifat, perubahan, dinamika, dan energetika zat. Oleh sebab itu, mata pelajaran kimia di SMA/MA mempelajari segala sesuatu tentang zat yang meliputi komposisi, struktur, sifat, perubahan, dinamika, dan energetika zat yang melibatkan keterampilan dan penalaran.

Secara jelas pendidikan kimia bertujuan untuk mengembangkan kemampuan memecahkan masalah melalui metode ilmiah, meningkatkan kesadaran tentang manfaat dan bahaya dari aplikasi kimia, serta penerapanya dalam kehidupan sehari-hari. Dari semua tujuan pembelajaran kimia perlu dijadikan arah sebagai implementasi pendidikan kimia disekolah. Kimia terjadi didalam kehidupan sehari-hari dan banyak yang menganggap kimia kurang menarik karena berhubungan dengan ide atau konsep yang abstrak dan memerlukan penalaran tinggi. Kesulitan pembelajaran kimia terletak pada kesenjangan yang 
terjadi antara pemahaman konsep dan penerapan konsep yang ada sehingga terjadi asumsi sulit untuk mempelajari.

Ada tiga karakterisitik pembelajaran kimia yaitu, makroskopik, submakroskopik dan simbolik. Ketiga karakterisitik tersebut memiliki hubungan seperti Gambar 1.

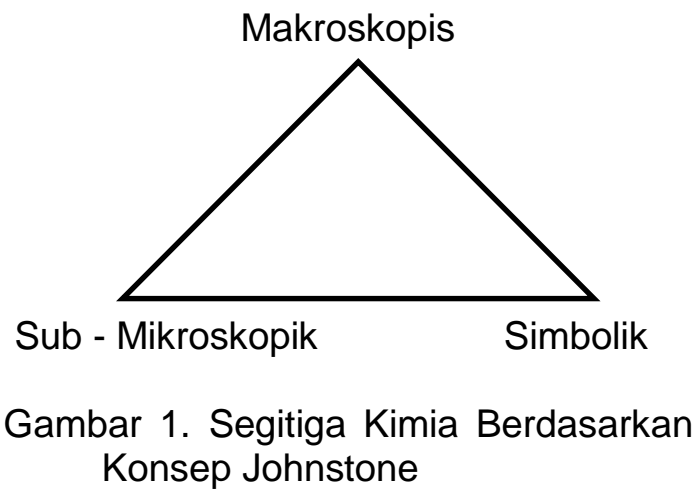

Level makro adalah fenomena yang dapat dilihat, disentuh dan dicium. Level submikro adalah fenomena yang tidak dapat diamati secara kasat mata. Sedangkan level representasional merupakan representasi submikro dalam bentuk simbol, rumus, persamaan, molaritas, perhitungan matematis dan grafik. Tingkatan itu saling berkaitan, sehingga jika siswa mengalami kesulitan disatu tingkat akan berpengaruh terhadap tingkat selanjutnya [1].

Sistem koloid merupakan salah satu materi yang terdapat pada pembelajaran kimia yang dapat dijelaskan melalui tiga level representasi kimia. Contoh yang relevan pada level makro dan nyata adalah tidak mengendapnya partikel terdispersi pada susu. Level submikro menjelaskan adanya gerak brown yang dilakukan oleh partikelpartikel koloid secara terus menerus sehingga dapat mengimbangi gaya gravitasi sehingga tidak terjadi pengendapan. Pada level representasional, gerak brown dapat diwujudkan melalui gambar dari mikroskop ultra.

Di dalam Kurikulum Tingkat Satuan Pendidikan (KTSP), kimia adalah salah satu mata pelajaran wajib untuk SMA kelas XI IPA. Dalam Standar Nasional Pendidikan (SNP Pasal 1 ayat 15) dijelaskan bahwa KTSP adalah kurikulum operasional yang disusun dan dilaksanakan oleh masing-masing satuan pendidikan. Penyusunan KTSP dilakukan oleh satuan pendidikan dengen memperhatikan dan berdasarkan standar kompetensi serta kompetensi dasar yang dikembangkan oleh Badan Standar Nasional Kependidikan (BNSP) [2]. Salah satu SMA yang masih menerapkan kurikulum KTSP adalah SMA N 2 Boyolali.

Berdasarkan hasil wawancara dengan guru kimia pada saat program praktik lapangan, materi kimia di kelas XI IPA semester genap yang dianggap siswa masih sulit dalam mempelajari dan ketuntasannya rendah adalah materi koloid. Penyampaian materinya juga masih menggunakan metode konvensional yaitu ceramah serta kurangnya penggunaan media pembelajaran sehingga siswa kurang tertarik dan lebih cenderung pasif. Kemudian berdasarkan hasil observasi dalam pembelajaran dan wawancara dengan guru, dapat dikatakan bahwa kegiatan pembelajaran masih belum menerapkan motde pembelajaran yang sesuai dengan KTSP, dimana siswa yang menjadi pusat bukan berpusat pada guru. Pada saat proses pembelajaran berlangsung, masih terdapat siswa yang kurang memperhatikan dan menanggapi pertanyaan yang diberikan guru. Siswa juga sulit memahami materi yang bersifat teori seperti koloid, dimana siswa cenderung menghafal dan belum mehamai konsep khususnya koloid.

Salah satu materi pokok kelas XI IPA adalah koloid. Koloid merupakan materi yang kimia yang bersifat konkret disamping ada yang bersifat abstrak dan juga merupakan materi yang bersifat konseptual serta berisi teori-teori saja. Siswa harus banyak menghafal banyak istilah baru sehingga siswa sulit untuk memahami maksud tersebut. Maka dari itu dalam pembelajaran kimia khususnya materi koloid membutuhkan kemampuan memori. Kemampuan memori atau ingatan secara sempit dapat diartikan sebagai kemampuan untuk menerima atau memasukkan kesan-kesan, menyimpan kesan-kesan yang pernah diterima [3]. Kemampuan memori berpengaruh terhadap prestasi belajar siswa dimana siswa dengan kemampuan 
memori tinggi memiliki prestasi lebih baik daripada siswa dengan kemampuan memori rendah [4].

Cara untuk mengatasi permasalahan tersebut yaitu dengan menerapkan model pembelajaran kooperatif yang sesuai serta media yang tepat sehingga siswa akan lebih termotivasi untuk mengikuti pembelajaran. Salah satu model pembelajaran kooperatif yang dapat digunakan adalah CIRC (Cooperative Integrated Reading and Composition) dilengkapi dengan media WebQuest. Salah satu fokus utama dari kegiatan CIRC sebagai cerita dasar adalah membuat penggunaan waktu tindak lanjut lebih efektif. Para siswa yang bekerja di dalam tim-tim kooperatif dari kegiatan-kegiatan ini yang dikoordinasikan dengan pengajaran kelompok membaca, kosa kata, pembacaan pesan dan ejaan. Para siswa bekerja sama dalam kegiatan ini atau rekognisi lainya yang didasarkan pada pembelajaran seluruh anggota tim [5]. Model pembelajaran CIRC lebih efektif daripada model pembelajaran konvensional [6]. Model pembelajaran CIRC juga mampu meningkatkan prestasi belajar kognitif dan afektif siswa, dibuktikan dengan prestasi belajar kognitif dan afektif siswa yang lebih tinggi daripada prestasi belajar kognitif dan afektif siswa dengan metode konvesional [7].

Cara yang digunakan untuk menyampaikan pembelajaran adalah dengan media pembelajaran. Media yang digunakan dalam pembelajaran ini adalah WebQuest. WebQuest merupakan media pemblejaran berupa paket halaman web yang di dalamnya terdapat tugas belajar dan kegiatan kerja siswa dengan sebagian besar atau semua informasi didalamnya berasal dari web yang dipilih guru. Tujuanya agar siswa fokus pada cara menggunakan dan menemukan informasi yang berkualitas di internet [8]. WebQuest yang dirancang dengan baik terdiri dari komponenkomponen: introduction, task, process resources, evaluation dan conclusion [9]. WebQuest efektif dalam mempromosikan keterlibatan siswa, motivasi, menghubungkan ke konteks otentik, berpikir kritis, kreativitas, meningkatkan keterampilan pemecahan masalah, interkasi sosial dan pembelajaran kooperatif [10].

\section{METODE PENELITIAN}

Penelitian ini merupakan Penelitian Tindakan Kelas (PTK) yang dilaksanakan dalam dua siklus. Setiap siklusnya terdapat empat tahapan, yaitu perencanaan, pelaksanaan, observasi, dan refleksi. Subjek penelitian adalah siswa kelas XI IPA 2 SMA Negeri 2 Boyolali tahun pelajaran 2016/2017. Pemilihan subjek dalam penelitian ini didasarkan pada hasil observasi, dimana subjek yang dipilih tersebut teridentifikasi mempunyai permasalahan dalam pembelajaran yaitu kemampuan memori dan prestasi belajar yang rendah.

Data yang dikumpulkan meliputi data tentang keadaan siswa yang berupa data tes dan non tes. Data non tes diperoleh dari hasil observasi, angket afektif, kajian dokumen dan wawancara. Data tes didapat dari hasil penilaian prestasi belajar siswa pada materi koloid yang meliputi afektif, kognitif, dan psikomotor.

Teknik analisis data pada penelitian ini menggunakan analisis deskriptif kualitatif. Analisis data menggunakan tiga tahap yaitu reduksi data, penyajian data dan penarikan kesimpulan [11].

\section{HASIL DAN PEMBAHASAN}

Penelitian tindakan kelas ini bertujuan untuk meningkatkan kemampuan memori dan prestasi belajar siswa kelas XI IPA 2 SMA N 2 Boyolali pada materi koloid melalui penerapan model pembelajaran CIRC dilengkapi media WebQuest. Instrumen kemampuan memori menggunakan metode asosiasi berpasangan, dimana subjek diminta untuk mempelajari materi secara berpasang-pasangan. Dalam pelaksanaannya siswa diminta untuk mengingat materi selama beberapa menit, berupa kata yang berpasangan dengan kode. Setelah itu materi ditarik dan siswa diminta untuk mengerjakan dengan mengungkapkan kembali materi yang telah diingat dengan memilih kode yang sesuai dengan 
pasanganya pada lembar jawab disertai dengan pengecoh. Prestasi belajar yang diukur meliputi prestasi belajar kognitif, afektif dan psikomotor.

Penelitian ini dilaksanakan dalam dua siklus yaitu siklus I dan siklus II. Masing-masing siklus terdiri dari tahap perencanaan, pelaksanaan, observasi dan refleksi [12]. Proses pembelajaran dilakukan secara berkelompok untuk meningkatkan kerja sama, kejujuran, tanggung jawab dalam kelompoknya.

\section{Siklus I}

\section{a. Perencanaan}

Pada tahap perencanaan siklus I dilakukan penyusunan silabus, RPP, WebQuest, instrumen penilaian kemampuan memori dan instrumen penilaian prestasi belajar. Berdasarkan silabus materi koloid memiliki alokasi waktu 8 jam pelajaran (8jp) dengan rincian 6 jp (6 $x 45$ menit) untuk penyampaian materi dan 2 jp ( 2 x 45 menit) untuk evaluasi siklus I.

\section{b. Pelaksanaan}

Pelaksanaan siklus I terdiri dari 4 kali tatap muka, dengan 3 kali penyampaian materi dan 1 kali untuk evaluasi siklus I. Pada pertemuan pertama sub pokok yang dipelajari yaitu mengklasifikasikan suspensi kasar, larutan sejati dan koloid serta mengelompokkan jenis-jenis koloid berdasarkan fase terdispersi dan medium pendispersi. Sebelum memulai pembelajaran guru mengkondisikan siswa agar duduk sesuai kelompok. Guru mengawali dengan memberi apersepsi berupa pertanyaan. Selanjutnya guru menjelaskan secara garis besar dan ringkas mengenai sistem dispersi dan penggolongan koloid. Setelah itu guru memberikan pertanyaan esensial tentang sistem koloid. Pertanyaan diajukan untuk memancing pengetahuan siswa. Beberapa siswa dengan antusias menjawab pertanyaan, hal ini dikarenakan siswa tersebut telah mempelajari dahulu materi yang diajarkan melalui WebQuest. Untuk mengeksplorasi jawaban yang lebih mendalam guru mempersilahkan siswa mencari informasi melalui webquest.

Saat siswa belajar bersama dengan kelompoknya guru memfasilitasi kegiatan tersebut agar proses pembelajaran dan penyampaian materi dapat berjalan dengan baik. Selanjutnya tiap kelompok diminta untuk membaca dan membuat ringkasan serta mengerjakan diskusi yang tertera pada menu task. Kemudian pada akhir pelajaran akan diadakan presentasi materi serta diskusi. Pada kegiatan penutup guru dan siswa melakukan refleksi hasil diskusi dan sebagai evaluasi pembelajaran diadakan posttest untuk mengetahui pemahaman siswa.

Pertemuan kedua dan ketiga hampir sama dengan pertemuan pertama, tetapi pada pertemuan ketiga akan diadakan praktikum di laboratorium. Pada pertemuan keempat, dilaksanakan evaluasi siklus I yang meliputi aspek kognitif, afektif dan kemampuan memori.

\section{c. Observasi}

Hasil penilaian observasi dan analisis hasil tes pada siklus I dapat dibuat dalam beberapa kategori. Hasil penilaian kemampuan memori siswa seperti pada Gambar 2.

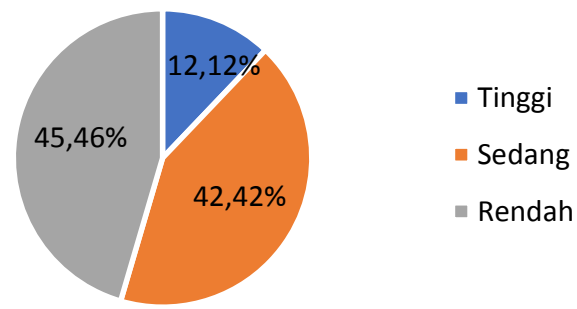

Gambar 2. Diagram Pie Kemampuan Memori Siswa Siklus I

Gambar 2 menunjukkan jika hasil kemampuan memori siswa masih rendah dan dibawah target yaitu $60 \%$ siswa masuk kategori tinggi dan sedang.

Hasil penilaian Kognitif bisa dilihat pada Gambar 3.

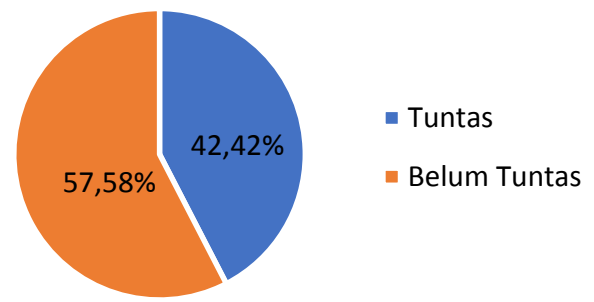

Gambar 3. Diagram Pie Tes Kognitif Siswa Siklus I 
Gambar 3 menunjukkan bahwa siswa yang tuntas masih dibawah target yaitu $70 \%$. Hasil siklus I terdapat dua indikator yang belum tuntas yaitu koloid liofil \& liofob serta permbuatan koloid.

Hal ini dikarenakan guru kurang mengkonfirmasi penjelasan yang konkrit mengenai perbedaan sifat koloid liofob dan liofil dan guru kurang menjelaskan secara mendetail. Rendahnya capaian pada indikator proses pembuatan koloid melalui percobaan juga disebabkan karena siswa hanya berpusat pada apa yang dipraktikumkan saja sedangkan pada indikator tersebut memiliki beberapa pembahasan yang lain.

Hasil angket dan observasi afektif seperti pada Gambar 4.

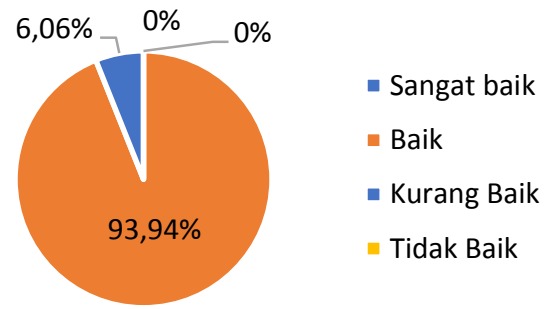

Gambar 4. Diagram Pie Afektif Siswa Siklus I

Gambar 4 menunjukkan jika capaian afektif siswa pada siklus I sudah baik dan melampaui target yaitu $70 \%$. Semua indikator sudah sudah mencapai target yang sudah ditentukan. Sikap siswa dalam pembelajaran di kelas sudah bagus sehingga mencapai target yang ditentukan. Penilaian afektif tetap dilakukan pada siklus II untuk melihat peningkatan afektif siswa.

Hasil observasi psikomotor siswa dapat dilihat pada Gambar 5.

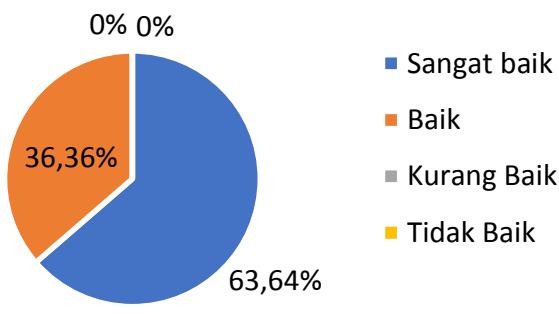

Gambar 5. Diagram Pie Psikomotor Siswa Siklus I

Gambar 5 menujukkan bahwa psikomotor siswa pada siklus I sudah baik dan melampaui target yang ditentukan yaitu $60 \%$. Hal ini dikarenakan siswa memahami apa yang diarahkan oleh guru tentang cara menggunakan alat-alat praktikum. Penilaian psikomotor hanya dilakukan pada siklus I dikarenakan pada siklus II tidak diadakan praktikum.

\section{d. Refleksi}

Hasil observasi yang dilakukan menunjukkan masih ada aspek yang belum memenuhi target yaitu aspek kognitif dan kemampuan memori. Oleh karena itu perlu dilakukan lagi pada siklus II agar dapat mencapai target, termasuk aspek afektif siswa dilaksanakan pada siklus II untuk melihat peningkatan.

\section{Siklus II}

\section{a. Perencanaan}

Perencanaan pada siklus II lebih difokuskan untuk perbaikan terhadap kendala-kendala pada siklus II. Materi yang diberikan juga merupakan indikator-indikator yang belum tuntas pada siklus I begitu juga untuk evaluasinya. Pada siklus II guru lebih memberikan perhatian khusus kepada siswa yang mengalami kesulitan belajar dan membantu tiap kelompok dalam menyelesaikan soal diskusi. Kelompok diskusi masih tetap sama pada siklus I, karena siswa sudah terbiasa bekerja sama dengan teman sekelompoknya pada siklus I.

\section{b. Pelaksanaan}

Pelaksanaan pada siklus II dilakukan sebanyak 2 kali pertemuan, yaitu 1 kali pembelajaran dan 1 kali evaluasi siklus II.

Guru memberi tahu bahwa pertemuan kali ini digunakan untuk mengulang kembali materi yang belum tuntas pada siklus I yaitu koloid liofil \& liofob serta pembuatan koloid. Pelaksanaan pada siklus II hampir sama dengan siklus I. Selama proses pembelajaran, guru sebagai fasilitator, mendampingi siswa mencari informasi dan mengarahkan siswa menyelesaikan tugas diskusi. Kemudian dilakukan presentasi pada beberapa kelompok. 
Kemudian guru dan siswa menyimpulkan pembelajaran yang telah dilaksanakan dan dilanjutkan dengan postest.

Pada pertemuan kedua dilakukan evaluasi siklus II yang meliputi tes kognitif, afektif dan kemampuan memori siswa.

\section{c. Pengamatan}

Hasil observasi dan analisis tes yang dilakukan pada siklus II dapat dilihat dari masing-masing aspek, yaitu kognitif, afektif dan kemampuan memori siswa. Hasil tes kemampuan memori siswa dapat dilihat pada Gambar 6.

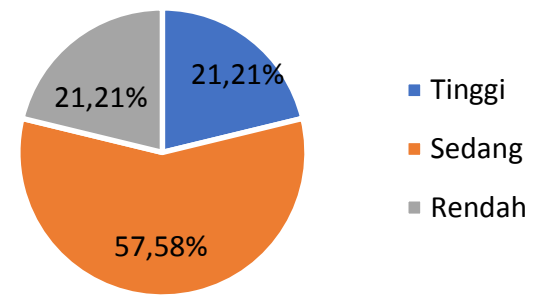

Gambar 6. Diagram Pie Kemampuan Memori Siswa Siklus II

Hasil pada Gambar 6 menunjukkan capaian siswa yang masuk dalam kategori tinggi dan sedang sudah melampaui target yaitu $60 \%$, sehingga penilaian kemampuan memori dilakukan sampai siklus II.

Hasil tes kognitif siswa pada siklus II disajikan pada Gambar 7.

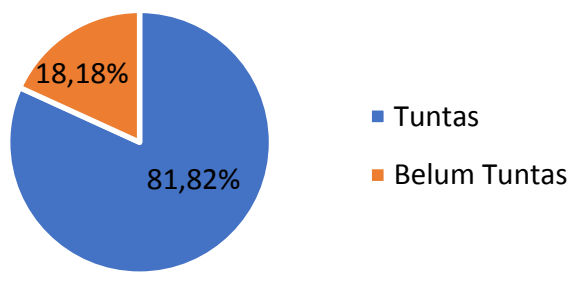

Gambar 7. Diagram Pie Kognitif Siswa Siklus II

Jumlah capaian kognitif siklus II sebesar $81,82 \%$, hasil ini sudah melampaui target yaitu $70 \%$. Semua indikator sudah mencapai target yang ditentukan, sehingga penilaian aspek kognitif siswa diakhiri pada siklus II.

Hasil angket dan observasi afektif siswa dapat dilihat pada Gambar 8.

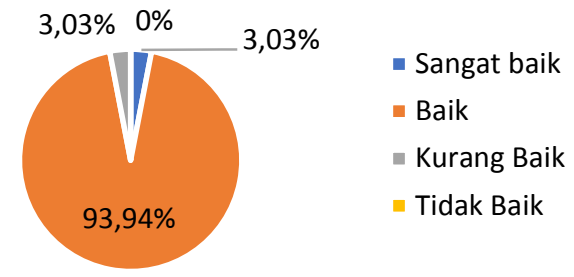

Gambar 8. Diagram Pie Afektif Siswa Siklus II

Dari gambar dapat dilihat bahwa terjadi kenaikan aspek afektif pada siklus II yaitu dari 93,94\% menjadi 96,97\% pada siklus II.

\section{Perbandingan Antar Siklus}

Berdasarkan hasil observasi, angket, tes dan wawancara yang telah dilakukan selama proses pembelajaran dengan model CIRC dilengkapi media webquest diperoleh data bahwa model pembelajaran tersebut dapat meningkatkan kemampuan memori dan prestasi belajar siswa. Data ketercapain kemampuan memori siswa siklus I danll disajikan pada Gambar 9.

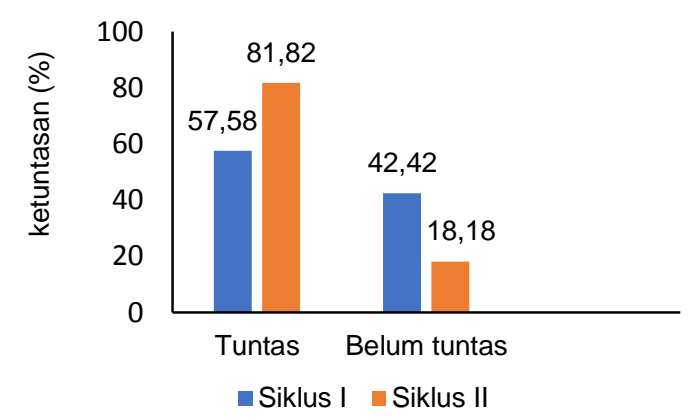

Gambar 9. Diagram Ketuntasan Kemampuan Memori Siklus I \& II

Berdasarkan Gambar 9, dapat dilihat kenaikan kemampuan memori siswa dari siklus I ke siklus II sebesar $24,25 \%$. Hal ini disebabkan dengan penggunaan model CIRC siswa dituntun untuk membaca, menulis dan mempresentasikan materi sehingga siswa akan lebih mudah mengingat dan memahami apa yang telah di pelajari. Dengan penggunaan model tersebut kemampuan memori siswa dapat dilatih dan ditingkatkan.

Kemudian prestasi belajar aspek kognitif siswa memiliki target sebesar $70 \%$ siswa tuntas. Pada siklus I terdapat 6 indikator yang harus dicapai, akan 
tetapi masih ada 2 indikator yang belum tercapai dan ketuntasan siswa hanya $57,58 \%$. Presentase ketuntasan aspek kognitif siklus I dan II ditunjukan pada Gambar 10.

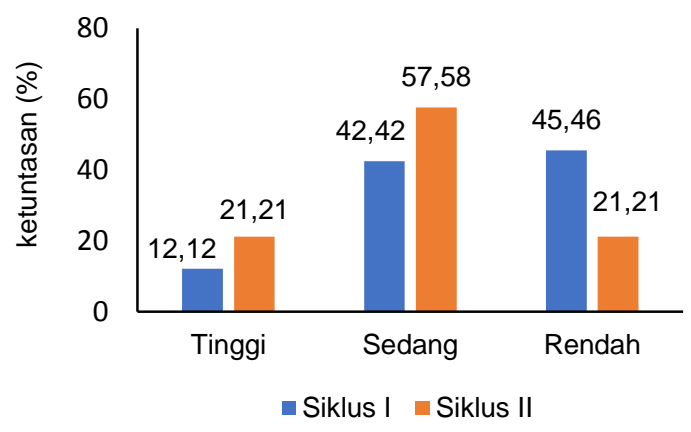

Gambar 10. Diagram Ketuntasan Kognitif Siklus I \& II

Pada siklus I diperoleh ketuntasan aspek kognitif sebesar $57,58 \%$ atau sebanyak 19 siswa tuntas. Hasil ini belum mencapai target yang ditentukan yaitu $70 \%$. Oleh karena itu pembelajaran dilanjutkan ke siklus II untuk meningkatkan aspek kognitif.

Hasil tes siklus II menunjukkan $81,82 \%$ siswa tuntas atau sebanyak 27 siswa tuntas. Penggunaan model pembelajaran CIRC dapat meningkatkan prestasi belajar siswa. Hal ini berarti hasil aspek kognitif pada siklus II telah mencapai target.

Aspek selanjutnya pada prestasi belajar adalah aspek afektif siswa. Aspek ini diukur dengan angket, observasi dan wawancara untuk menguatkan data afekif siswa. Kategori ketuntasan afektif terdiri dari sangat baik, baik, kurang baik dan tidak baik. Ketercapaian afektif siswa disajikan pada Gambar 11.

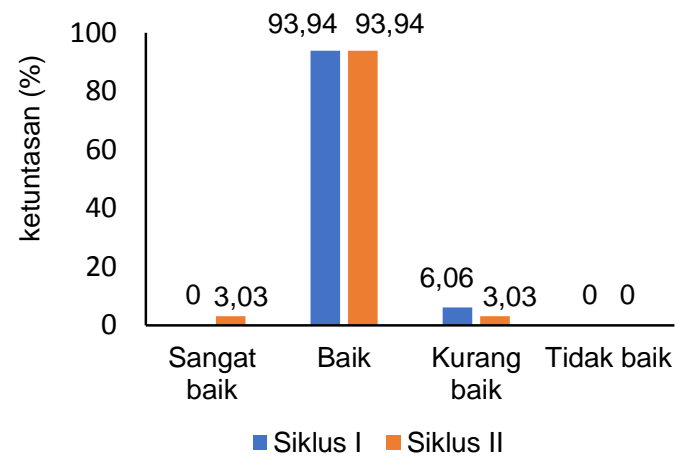

Gambar 11. Diagram Ketuntasan Afektif Siklus I \& II
Hasil pencapaian siswa sudah mencapai target yang sudah ditentukan yaitu $70 \%$. Pada siklus I mencapai 93,94\% dan dilakukan lagi pada siklus untuk melihat adanya peningkatan. Hasil data yang diperoleh pada siklus II mengalami peningkatan menjadi $96,97 \%$. Sikap siswa dalam pembelajaran secara keseluruhan sudah baik sehingga hasil penilaian siswa secara keseluruhan juga baik.

Aspek prestasi belajar yang terakhir adalah psikomotor siswa. Aspek ini diukur dengan menggunakan praktikum yang hanya dilaksanakan pada siklus I. Hasil pencapaian siswa sudah melebihi target dan sudah mencapai $100 \%$.

Hasil penilaian yang diperoleh pada siklus II menujukan bahwa penelitian tindakan kelas ini berhasil karena semua aspek yang diukur sudah memenuhi target. Peningkatan hasil dari siklus I ke siklus II disebabkan oleh: (1) penguatan materi mengenai indikator yang belum tuntas; (2) guru lebih memfokuskan pada siswa yang mengalami kesulitan belajar dan membantu tiap kelompok mengerjakan diskusi.

Berdasarkan hasil tersebut, penelitian dengan model pembelajaran Cooperative Integrated Reading and Composition (CIRC) dilengkapi media WebQuest dikatakan berhasil karena pada akhir penelitian semua aspek telah memenuhi target yang ditentukan.

\section{KESIMPULAN}

Berdasarkan hasil penelitian yang telah dilakukan, dapat disimpulkan bahwa penerapan model pembelajaran Cooperative Integrated Reading and Composition (CIRC) dilengkapi media WebQuest pada materi koloid kelas XI IPA 2 SMA N 2 Boyolali Tahun Pelajaran 2016/2017 dapat meningkatkan kemampuan memori dan prestasi belajar siswa. Ketercapaian kemampuan memori siswa pada siklus I sebesar $54,54 \%$ menjadi $78,79 \%$ pada siklus II. Peningkatan prestasi belajar terlihat pada aspek kognitif siswa pada siklus I 57,58\% menjadi $81,82 \%$ pada siklus II. Aspek afektif siswa pada siklus I 93,94\% 
menjadi 96,97\% pada siklus II. Aspek psikomotor siswa telah mencapai 100\%.

\section{UCAPAN TERIMA KASIH}

Penelitian ini dapat dilaksanakan dengan baik karena bantuan dari banyak pihak. Penulis mengucapkan terima kasih kepada Kepala SMA N 2 Boyolali, Bapak Drs. Makno, M.H atas izin melakukan penelitian, dan kepada guru kimia kelas XI Ibu Nur Heni W S.Pd yang mem-berikan bimbingan selama penelitian, serta siswa-siswi kelas XI IPA 2 SMA N 2 Boyolali tahun pelajaran 2016/2017 yang telah membantu dalam menyelesaikan penelitian ini.

\section{DAFTAR RUJUKAN}

[1] Sirhan, G. (2007). Journal of Turkish Science Education, 4(2), 1-20.

[2] Sanjaya, W. (2008). Teori dan Praktik Pengembangan Kurikulum Tingkat Satuan Pendidikan (KTSP). Jakarta: Kencana.

[3] Walgito, B. (2005). Pengantar Psikologi Umum: Yogyakarta: Andi Offset.

[4] Antoro, Y.G., Utomo, B.U., \& Masykuri, M. (2016). Jurnal Pendidikan Kimia, 5(3). 1-8
[5] Slavin, R. E. (2005). Cooperative Learning Teori, Riset dan Praktik. Terj. N. Yusron. Bandung: Nusa Media.

[6] Durukan, E. (2011). Educational Research and Reviews, 6 (1).

[7] Sastika, A.R., V.H. Elfi Susanti., \& Ashadi. (2013). Jurnal Pendidikan Kimia, 2(3). 42-48.

[8] New Jersey Coalition for Inclusive Education (NJCIE). (2009). Keys to Inclusion: The WebQuest Issue. New Jersey: The New Jersey Coalition for Inclusive Education.

[9] Rachmawati, U. \& Madya. (2014). Jurnal Kependidikan, 44(1), 82-91.

[10] Yasemin, M, \& Kalelioglu. (2010). Educational Technology \& Society, 13(3), 139-15.

[11] Sugiyono. (2010). Metode Penelitian Pendidikan. Bandung: Alfabeta.

[12] Arikunto, S. (2010). Prosedur Penelitian Suatu Pendekatan Praktik. Jakarta: Rineka Cipta. 